\title{
Growth of Forbs, Shrubs, and Trees on Bentonite Mine Spoil Under Greenhouse Conditions
}

\author{
DANIEL W. URESK AND TERUO YAMAMOTO
}

\begin{abstract}
Revegetation on raw bentonite spoil with or without treatments is often more practical than replacing topsoil in areas where it is scarce or nonexistent. The effect of raw bentonite spoil treated with ponderosa pine sawdust on plant survival and growth was compared to other treatments including perlite, gypsum, straw, vermiculite, and no treatment. Plants tested were the drought- and salt-resistant species of fourwing saltbush (Atriplex canescens (Pursh) Nutt.), rubber rabbitbrush (Chrysothamnus nauseousus (Pallo) Britt.), big sagebrush (Artemisia tridentata tridentata Nutt.), common winterfat (Ceratoldes lanata (Pursh) Moq.), Rocky Mountain juniper (Juniperus scopulorum Sarg.), Russian olive (Elaegnus angustijolia L.), common yarrow (Achillea millifolium L.), and desert globemallow (Sphaeralcea ambigua Gray). Desert globemallow, fourwing saltbush, and rubber rabbitbrush had substantial growth and survival on sawdust, perlite, and vermiculite treated spoil. The growth promoting effect of sawdust is particularly promising; it is readily available and cost is minimal.
\end{abstract}

Bentonite, a cream to greenish-gray colored clay consisting of the mineral montmorillonite (Gries 1974), occurs in much of the northern Great Plains as widespread beds interstratified with the dark gray marine shales. Bentonite mine spoil is commonly described as shales containing sodium montmorillonite. When wet, the bentonite spoil swells, and infiltration, permeability, and aeration approach zero. Excessive salt concentrations increase the osmotic potential of the spoil solution to a level that can be toxic to plants. Because of these problems, revegetation of bentonite mine spoil in arid and semiarid regions of the northern Great Plains, is extremely difficult (Bjugstad 1979).

Several factors can be employed to improve revegetation efforts: (1) improving the physical and chemical conditions of the spoils, (2) covering bentonite spoils with topsoil and more favorable overburden, (3) using the most salt adaptable plants (Shannon 1979), (4) developing new genetic strains of salt adaptable plants for the future (Epstein et al. 1980), or (5) utilizing drip irrigation systems, but this may be expensive.

Replacing the original topsoil to bentonite spoil has improved plant survival somewhat (Bjugstad 1979, Dollhopf et al. 1980, Dollhopf and Bauman 1981). However, much of the bentonite land has only shallow surface soil-less than $15 \mathrm{~cm}$. In many places it is not practical to restore the original soil to bentonite-mined lands. This study was initiated to determine, based on greenhouse trials, the plant species most adaptive to spoil conditions and spoil amend ments conducive to plant growth and establishment without topsoil.

\section{Methods}

\section{Spoil Collection and Analysis}

Bentonite spoil substrate for the greenhouse trials was collected from 6 sites $(20 \mathrm{~cm}$ depth) on the property of the American Colloid Company in Upton, Wyo. The spoil is shale of the cretaceous Belle Fourche and Mowry formation (USGS 1975). Spoil from the sites was air dried, composited for greenhouse trials. Chemical and physical properties of the composite 6 spoil samples were analyzed at the United States Testing Company, Inc., Richland Laboratory,

\footnotetext{
Uresk is research biologist, Yamanoto was geologist, now retired, with the Rocky Mountain Forest and Range Experiment Station, Rapid City, South Dakota 57701 , in cooperation with the South Dakota School of Mines and Technology. The Station's headquarters is in Fort Collins, in cooperation with Colorado State University.

Manuscript accepted 9 July 1985.
}

Richland, Washington, following agricultural soil analysis procedures (USTC n.d.). These analyses included $\mathrm{NO}_{3}-\mathrm{N}, \mathrm{NH}_{3}-\mathrm{N}, \mathrm{P}, \mathrm{K}$, $\mathrm{Ca}, \mathrm{Mg}, \mathrm{S}, \mathrm{B}, \mathrm{Zn}, \mathrm{Mn}, \mathrm{Cu}, \mathrm{Fe}$, electrical conductivity(EC), sodium absorption ratio (SAR), exchangeable sodium percentage (ESP), pH, organic matter (OM), and cation exchange capacity (CEC). Clay minerals were identified at the Engineering and Mining Experiment Station of the South Dakota School of Mines and Technology.

\section{Spoil Treatments}

Each spoil treatment included gypsum, fertilizer (nitrogen $(\mathrm{N})$, phosphate $(P)$, potassium $(K)$ ), and a surface mulch of ponderosa pine woodchips. Physical amendments of organic (sawdust, woodchips) and inorganic materials were added in all but one of the spoil treatments. An 11-5-6 (NPK) fertilizer was added at $84 \mathrm{~kg} / \mathrm{ha}$. When sawdust and straw were incorporated into the spoil, additional nitrogen (dry pellet) was added, equivalent to $12 \mathrm{~kg} / \mathrm{MT}$ (metric ton) of dry ponderosa pine sawdust and $8 \mathrm{~kg} / \mathrm{MT}$ of dry wheat straw, respectively. For the gypsum treatment, gypsum was added equivalent to $20 \mathrm{MT} /$ ha to a $30-\mathrm{cm}$ depth of spoil (USSLS 1954). Gypsum was applied at $10 \mathrm{MT} /$ ha to adjust for the $50 \%$ reduction in spoil volume, for sawdust, straw, perlite, and vermiculite treatments (Table 1).

Table 1. Six bentonite spoil treatments for greenhouse trials.

\begin{tabular}{|c|c|}
\hline Treatment & Amendments \\
\hline Control & Spoil with no treatment \\
\hline Gypsum & Gypsum and NPK fertilization \\
\hline Sawdust & $\begin{array}{l}\text { Gypsum and NPK fertilization with sawdust } \\
\text { mixed into spoil at 50:50 volume ratio. }\end{array}$ \\
\hline Straw & $\begin{array}{l}\text { Gypsum and NPK fertilization with wheat straw mixed } \\
\text { into spoil at 50:50 volume ratio. }\end{array}$ \\
\hline Perlite & $\begin{array}{l}\text { Gypsum and NPK fertilization with perlite mixed into } \\
\text { spoil at 50:50 volume ratio. }\end{array}$ \\
\hline Vermiculite & $\begin{array}{l}\text { Gypsum and NPK fertilization with vermiculite mixed } \\
\text { into spoil at 50:50 ratio. }\end{array}$ \\
\hline
\end{tabular}

\section{Plant Species Accessions}

The 8 plant species selected on the basis of potential drought and saline-alkali tolerance (Wright and Bretz 1949, Gill 1949, McKell 1978) were: fourwing saltbush (Atriplex canescens (Pursh) Nutt.), rubber rabbitbrush (Chrysothamnus nauseousus (Pallo) Britt.), big sagebrush (Artemisia tridentata tridentata Nutt.), common winterfat (Ceratoides lanata (Pursh) Moq.), Rocky Mountain juniper (Juniperus scopulorum Sarg.), Russian olive (Elaegnus angustifolia L.), common yarrow (Achillea millifolium L.), and desert globemallow (Sphaeralcea ambigua Gray).

Rocky Mountain juniper and Russian olive were respectively 11/2- 3-year-old bare root seedlings, obtained from U.S. Forest Service, Bottineau, N.Dak. The remaining species were 1-year-old seedlings, obtained as container grown stock from a commercial supplier in Salt Lake City, Utah. All plants were planted in 9.5-liter pots with $1.3-\mathrm{cm}$-square drainage vents. Each plant was thoroughly watered, then placed in the middle of the pot and backfilled with the spoil mix (Table 1). The spoil surface was then covered with $3.8 \mathrm{~cm}$ of woodchip mulch, and each pot was watered 
to saturation. Plants were started in May, and the study ended 17 months later.

\section{Greenhouse Culture}

No regular watering scheme was followed since tensiometers in each pot did not work well in the bentonite spoil. In addition, the plants were used as indicators (leaf color, wilting, soil) of water need. All treatments were monitored equally on a daily basis. During the first month (May) after planting, the controls required watering once a week with 250 to $500 \mathrm{ml}$ of deionized water. The treated pots required little water during this period. From midJune through August, all pots required an average of about 250 to $400 \mathrm{ml}$ of water once per week. Watering needs gradually diminished after September to about $200 \mathrm{ml}$ per plant per week. This watering regime was repeated for the summer months of the second year until the end of the study in September. The air temperature in the greenhouse ranged from $8.3^{\circ} \mathrm{C}$ to $26.7^{\circ} \mathrm{C}$. Soil temperature within the pots varied from $8.3^{\circ} \mathrm{C}$ to $22.8^{\circ} \mathrm{C}$. The relative humidity ranged from $47 \%$ to $70 \%$ during this study. Air temperature and relative humidity were measured by a hygro-thermograph recorder. Thermometers in several pots were used to measure soil temperature.

A latin square design ( 6 plants/species/treatment) provided the statistical randomization necessary to isolate the variations (light, temperature, humidity) in the greenhoúse in excess of those differences being tested.

Morphometric characteristics of plants were measured at the beginning of the study and end of 17 months. These measurements were: plant height, length, (length of widest section of plant), and width (measured at right angle to length), leaf length, twig length (including terminal twig), number of branches, and number of leaves. Twenty-four measurements of each parameter were taken of each shrub. All plants were harvested at spoil level and were separated into leaves and stems. Plant parts were oven dried at $60^{\circ} \mathrm{C}$ for 96 hours and were weighed. Survival counts also were taken.

\section{Statistical Methods}

Differences in morphometry and biomass between treated and control plants were analyzed using analysis of variance and the F-protected LSD (Carmer and Swanson 1973). Differences were accepted at $\alpha=0.10$. A $\log$ transformation was used to remove variance heterogenity among treatment groups when it occurred. Treatment effects on plant survival were analyzed by Chi square techniques. The Bonferroni $t$ statistic was used to test differences ( $\alpha$ $=0.10$ ) in spoil pH between treatments and control (Miller 1966).

\section{Results}

\section{Physical and Chemical Properties}

Average chemial and physical properties of bentonite spoil from Belle Fourche and Mowry shale are presented in Table 2. Of special note was the fact that sulfur, a micronutrient in the spoil, was present in large quantities (326 ppm), and the spoil material was slightly acidic, $\mathrm{pH}$ 6.8. Total salt concentration, as indicated by an $\mathrm{EC}$ of $0.92\left(\mathrm{~S} \mathrm{~m}^{-1}\right)$, was high for most plants. Sodium adsorption ratios (15 to 56 ) and exchangeable sodium percentages (15 to 46) were high. Mineral analysis showed that montmorillonite, illite, and kaolinite clays were the major components of the spoil, followed by quartz and feldspars. Spoil texture analyses showed clays were the major components $(48.0-70.0 \%)$, followed by silt and sand.

The pH of control spoil (8.1) was significantly $(P \leq 0.10)$ greater than sawdust treated spoil (7.3) at the end of this study. No other amendments at the end of 17 months produced significant differences with the untreated spoil. The $\mathrm{pH}$ of raw ponderosa sawdust ranged from 4.6 to 4.7 , and contributed to the buffering of salinealkali spoils to near neutral (pH 7.3).

\section{Plant Survival}

Survival rates on controls (6 plants/species/treatment) are
Table 2. Chemical, mineral, and textural properties of Belle Fourche and Mowrey shale spoil (composite sample from six randomly selected points; 0-20 cm depth; Voorhees (1984) and Sieg et al. (1984) present variability for chemistry among spoil sites.)

\begin{tabular}{|c|c|}
\hline Properties & Values \\
\hline $\begin{array}{l}\text { Macronutrients } \\
\mathrm{NO}_{3}-\mathrm{N}, \mathrm{kg} / \mathrm{ha}-30 \mathrm{~cm}^{1} \\
\mathrm{NH}_{4}-\mathrm{N}, \mathrm{kg} / \mathrm{ha}-30 \mathrm{~cm} \\
\mathrm{P}, \mathrm{ppm} \\
\mathrm{K}, \mathrm{ppm} \\
\mathrm{Ca}, \mathrm{meq} / 100 \mathrm{~g} \\
\mathrm{Mg}, \mathrm{meq} / 100 \mathrm{~g}\end{array}$ & $\begin{array}{r}19 \\
55 \\
39 \\
170 \\
17.4 \\
3.7\end{array}$ \\
\hline $\begin{array}{l}\text { Micronutrients } \\
\text { S, ppm } \\
\text { B, ppm } \\
\text { Zn, ppm } \\
\text { Mn, ppm } \\
\text { Cu, ppm } \\
\text { Fe, ppm }\end{array}$ & $\begin{array}{l}326 \\
2 \\
3.2 \\
31 \\
4.2 \\
102\end{array}$ \\
\hline $\begin{array}{l}\text { Ec, electrical conductivity, } \mathrm{S} \mathrm{m}^{-1} \\
\text { SAR, sodium absorption ratio } \\
\text { ESP, exchangeable sodium percentage, } \%^{2} \\
\text { pH } \\
\text { Om, organic matter, } \% \\
\text { CEC, cation exchange capacity, meq } / 100 \mathrm{~g}\end{array}$ & $\begin{array}{l}0.92 \\
33.1 \\
31.8 \\
6.8 \\
1.1 \\
30\end{array}$ \\
\hline $\begin{array}{l}\text { Mineral analysis (\%) } \\
\text { Sample } 1 \\
\left.\text { Clays: Montmorillonite ( } \mathrm{Na}-\mathrm{Al}-\mathrm{Mg}-\mathrm{Si}-\mathrm{O}-\mathrm{OH}-\mathrm{H}_{2} \mathrm{O}\right) \\
\text { Illite (trioctohedra, K-Na-Ca-Mg-Al-Fe-Ti-Si-O) } \\
\text { Kaolinite }\end{array}$ & 48 \\
\hline $\begin{array}{l}\text { Quartz } \\
\text { Feldspars }\end{array}$ & $\begin{array}{l}20 \\
32\end{array}$ \\
\hline $\begin{array}{l}\text { Sample } 2 \\
\text { Clays: Montmorillonite }\left(\mathrm{Na}-\mathrm{Al}-\mathrm{Mg}-\mathrm{Si}-\mathrm{O}-\mathrm{OH}-\mathrm{H}_{2} \mathrm{O}\right) \\
\left.\text { Illite }\left[\text { sodium, }[\mathrm{Na}, \mathrm{K}) \mathrm{Al}_{2} \mathrm{SI}_{3} \mathrm{Al} \mathrm{O}_{10}\right)\left(\mathrm{OH}_{2}\right)\right] \\
\text { Kaolinite }\end{array}$ & 45 \\
\hline $\begin{array}{l}\text { Quartz } \\
\text { Feldspar }\end{array}$ & $\begin{array}{l}45 \\
11\end{array}$ \\
\hline
\end{tabular}

'Values extrapolated to a $30 \mathrm{~cm}$ depth.

${ }^{2}$ Average of 5 samples.

often, but not always, a clue to a plant's natural adaptability to a problem soil. Survival rates on the control (Table 3) indicate that: common yarrow, Russian olive, and Rocky Mountain juniper were the least adaptable to untreated spoils; big sagebrush, fourwing saltbush, and winterfat had intermediate adaptability; rabbitbrush and desert globemallow were the most adaptable. Survival of common yarrow, big sagebrush, fourwing saltbush, winterfat, and Rocky Mountain juniper was higher with spoil treatment. Overall survival with treatment indicated that desert globemallow (97\%), fourwing saltbush $(92 \%)$, and rubber rabbitbrush $(89 \%)$ were the most adaptable species on bentonite spoil.

Collation of overall survival rates by treatments indicated that sawdust $(83 \%)$, perlite, $(81 \%)$, and vermiculite $(79 \%)$ resulted in greater plant survivals than the other treatments (Table 3). Five species of plants had $100 \%$ survival with the sawdust bentonite spoil treatment.

\section{Plant Response}

The effect of spoil amendments upon plant growth is expressed by changes or compared to the control in morphological characteristics and biomass. Those characteristics give an indication of plant vigor and response to spoil treatment.

\section{Fourwing Saltbush}

Height of plants was significantly greater on sawdust, perlite, gypsum, and vermiculite amended spoil than on the control. Dif- 
Table 3. Survival of plants by spoil treatments and species in the greenhouse.

\begin{tabular}{|c|c|c|c|c|c|c|c|}
\hline \multirow[b]{2}{*}{ Species } & \multicolumn{7}{|c|}{ Treatment } \\
\hline & Control & Gypsum & Perlite & Sawdust & Straw & Vermiculite & $\%$ Survival \\
\hline Yarrow & $\overline{01}$ & 4 & 6 & 6 & 1 & 1 & $50^{\mathrm{abc2}}$ \\
\hline Big Sagebrush & 2 & 4 & 5 & 4 & 5 & 6 & $67^{\text {bod }}$ \\
\hline Fourwing Saltbush & 3 & 6 & 6 & 6 & 6 & 6 & $92^{d}$ \\
\hline Rabbitbrush & 5 & 4 & 6 & 6 & 5 & 6 & $89^{\text {cd }}$ \\
\hline Russian olive & 0 & 1 & 1 & 1 & 1 & 3 & $19^{*}$ \\
\hline Winterfat & 2 & 3 & 4 & 5 & 4 & 5 & $64^{\text {bod }}$ \\
\hline R.M. Juniper & 1 & 0 & 5 & 6 & 0 & 5 & $44^{\mathrm{ab}}$ \\
\hline Desert Globemallow & 6 & 5 & 6 & 6 & 6 & 6 & $97^{\mathrm{d}}$ \\
\hline$\%$ Survival & $40^{\mathrm{a}}$ & $56^{\mathrm{ab}}$ & $81^{b}$ & $83^{b}$ & $60^{\text {ab }}$ & $79^{b}$ & \\
\hline
\end{tabular}

Numbers surviving 6 plants per treatment.

2Means followed by the same letter are not different at $\alpha=0.10$

ferences in twig length were observed with sawdust and vermiculite treatments. However, no differences were found among spoil treatments for number of branches and leaf length. Biomass of leaves and stems was greater with spoil treatment (Table 4). Greatest biomass was obtained with sawdust and vermiculite treatments for both leaves and stems.

\section{Rubber Rabbitbrush}

Morphological measurements of height, number of branches, twig length, and leaf length did not indicate a response to spoil treatments. However, leaf biomass was significantly higher on the sawdust treatment than on the control (Table 4). Stem biomass was greater with the vermiculite treatment.

\section{Common Winterfat}

Height, number of branches, twig length, and leaf length measurements of common winterfat did not differ between treatments and the control. Stem biomass was greater on all spoil treatments when compared to the control (Table 4). Sawdust, perlite, and vermiculite spoil treatments showed the highest stem biomass estimates. No differences were observed among treatments for leaf biomass.

\section{Big Sagebrush}

Big sagebrush showed a significant positive response in height and width measurements with sawdust, perlite, and vermiculite treatments. Biomass of leaves and stems increased with the same treatments (Table 4).

\section{Desert Globemallow}

The hardiness of desert globemallow was demonstrated by $100 \%$ survival on the control. It responded to spoil treatments with increased morphological measurements except for height. Biomass of leaves and stems showed the same significant positive response to treatments (Table 4).

\section{Rocky Mountain Juniper}

Rocky Mountain juniper was poorly adapted to bentonite spoil. After 6 months, many of the plants showed stress symptoms of bluish-green leaves which were coated with a waxy deposit. Survival was low except on perlite, sawdust, and vermiculite spoil treatments (Table 4).

\section{Russian Olive}

Russian olive performed most poorly of all the plant accessions. Survival was so low that reasonable morphometric and biomass evaluations were not possible (Table 3 ). The species commonly suffered from leaf chlorosis and lacked vigor throughout the test period.

\section{Common Yarrow}

Common yarrow plants flowered soon after planting, and stems died back and new stems emerged throughout the study period. Of the surviving plants, growth increases were more consistent with the sawdust treatment (Table 4).

\section{Discussion}

Revegetation of bentonite spoil is more difficult than generally recognized. The spoil material in itself is not conducive to growth of most plants. The physical and chemical properties of bentonite spoil are heterogeneous and generally difficult to characterize (Sieg

Table 4. Average biomass (g/plant) of shrubs and forbs grown in six treatments of bentonite spoils in the greenhouse.

\begin{tabular}{|c|c|c|c|c|c|c|}
\hline \multirow[b]{2}{*}{ Treatment } & \multicolumn{6}{|c|}{ Plant Species } \\
\hline & Fourwing saltbush & Rubber rabbitbrush & Common winterfat & Big sagebrush & Desert globemallow & Common yarrow \\
\hline $\begin{array}{l}\text { Sawdust } \\
\text { Perlite } \\
\text { Gypsum } \\
\text { Straw } \\
\text { Vermiculite } \\
\text { Control }\end{array}$ & $\begin{array}{l}5.4 \pm 1.0^{*} \\
3.8 \pm 0.4^{*} \\
3.4 \pm 0.6^{*} \\
4.8 \pm 0.4^{*} \\
5.9 \pm 1.1^{*} \\
1.9 \pm 0.2\end{array}$ & $\begin{array}{l}0.8 \pm 0.3^{*} \\
0.6 \pm 0.2 \\
0.4 \pm 0.2 \\
0.3 \pm 0.1 \\
0.6 \pm 0.2 \\
0.4 \pm 0.1\end{array}$ & $\begin{array}{l}2.8 \pm 1.0 \\
2.6 \pm 0.7 \\
1.6 \pm 0.4 \\
1.7 \pm 0.6 \\
2.4 \pm 0.3 \\
1.8 \pm 0.2\end{array}$ & $\begin{array}{l}1.7 \pm 0.5^{*} \\
1.3 \pm 0.3^{*} \\
0.3 \pm 0.1 \\
0.4 \pm 0.1 \\
1.4 \pm 0.4^{*} \\
0.2 \pm 0.1\end{array}$ & $\begin{array}{l}3.5 \pm 0.4^{*} \\
3.8 \pm 0.3^{*} \\
3.7 \pm 1.2^{*} \\
3.2 \pm 0.4^{*} \\
3.4 \pm 0.8^{*} \\
1.5 \pm 0.2\end{array}$ & $\begin{array}{l}4.2 \pm 0.2 \\
2.8 \pm 0.7 \\
0.5 \pm 0.2 \\
1.8 \\
2.8\end{array}$ \\
\hline $\begin{array}{l}\text { Sawdust } \\
\text { Perlite } \\
\text { Gypsum } \\
\text { Straw } \\
\text { Vermiculite } \\
\text { Control }\end{array}$ & $\begin{array}{r}10.2 \pm 1.8^{*} \\
8.2 \pm 1.4^{*} \\
7.3 \pm 1.5^{*} \\
6.6 \pm 0.6^{*} \\
10.2 \pm 1.5^{*} \\
2.7 \pm 0.3\end{array}$ & $\begin{array}{l}1.4 \pm 0.5 \\
1.8 \pm 0.4 \\
1.2 \pm 0.5 \\
1.0 \pm 0.4 \\
2.1 \pm 0.4^{*} \\
1.1 \pm 0.5\end{array}$ & $\begin{array}{l}3.9 \pm 1.0^{*} \\
4.0 \pm 1.0^{*} \\
2.7 \pm 0.2^{*} \\
2.5 \pm 0.9^{*} \\
4.0 \pm 0.7^{*} \\
1.6 \pm 0.1\end{array}$ & $\begin{array}{l}0.8 \pm 0.1^{*} \\
0.6 \pm 0.2^{*} \\
0.1 \pm 0.0 \\
0.3 \pm 0.2 \\
0.5 \pm 0.2^{*} \\
0.1 \pm 0.0\end{array}$ & $\begin{array}{l}2.9 \pm 0.4^{*} \\
2.4 \pm 0.3^{*} \\
3.1 \pm 0.8^{*} \\
1.7 \pm 0.2^{*} \\
3.6 \pm 0.6^{*} \\
0.6 \pm 0.2\end{array}$ & $\begin{array}{l}2.0 \pm 0.4 \\
1.0 \pm 0.4 \\
0.6 \pm 0.2 \\
0.2 \\
1.7\end{array}$ \\
\hline
\end{tabular}

Mean \pm standard error, $n=6$ plants $/$ treatment

2Significantly different from control at $\alpha=0.10$. 
et al. 1983, Voorhees 1984). Spoil analysis shows high EC, SAR, and ESP values, indicating that revegetation problems are associated with high salt and sodium concentrations. Total salt concentrations, indicated by EC of $0.92\left(\mathrm{~S} \mathrm{~m}^{-1}\right)$, were far above the threshold value of 0.4 for growth of most agronomic plants (USSLS 1954), suggesting that plant growth was restricted to salt tolerant species only. The ranges of SAR (15-56) and ESP (15-46) values indicate the great variability in problems associated with salt toxicity, osmotic potential, and exchangeable sodium.

Exchangeable sodium in shale spoils because of its course texture is related more to properties of swelling and less to structural dispersion and slaking as reported for alkali soils. Elevated $\mathrm{pH}$ values of 8.5 or higher are related to high SAR values in sodic soils (USSLS 1954). The pH value of 6.8 in bentonite spoil may result from the formation of sulfuric acid from inherent sulfate ions (USSLS 1954, Allen 1977, Sieg et al. 1983) which neutralizes the alkaline effects of the spoil. A high level of sulfur seems to support this supposition. The clay content amounts to nearly $50 \%$ of the total mineral composition. However, the cation exchange capacity of $30 \mathrm{meq} / 100 \mathrm{~g}$ is nominal (Tisdale and Nelson 1975) in comparison to reported capacities of more than $100 \mathrm{meq} / 100 \mathrm{~g}$ for bentonite clays (Grim 1953). The lower cation exchange capacity may result in the removal of exchangeable sodium (Grube et al. 1971). However, the fine texture and swelling inhibit rapid leaching of salts and sodium ions.

Spoil pH apparently changed with sawdust treatment because of the enhanced drainage which lowers the concentration of soluble salts in the spoil solution. The consensus from the literature is that saline-alkali soil may become more strongly alkaline upon dilution or leaching (Baver 1927, Snyder 1935, Carolus and Lucas 1943, USSLS 1954, Peech 1965). Soluble salts are leached downward and soil may become strongly alkaline because some of the exchangeable sodium hydrolyzes and forms sodium hydroxide. This is also true for the change in $\mathrm{pH}$ on the controls from 6.8 to 8.1. Nevertheless, the specific contribution of lowered $\mathrm{pH}$ to growth and survival is uncertain because (1) the plants responded equally well to the other treatments and (2) some species (e.g., fourwing saltbush) exhibit wide tolerance to chemical and ecological stresses.

Mulch, fertilizer (NPK), chemical binder (gypsum), and physical amendments (sawdust, straw, perlite, vermiculite) contributed in some degree to promoting establishment of plants in a saline-alkali spoil, which becomes essentially impermeable with swelling. The physical amendments were observed to provided rapid improvement in physical conditions that often are unattainable with chemical binder only. However, straw does not mix well with dry bentonite spoil, which is hard and crusty, unless the spoil is commuted to soil $(<2 \mathrm{~mm})$ or small gravel-size textures. Excessive communion was avoided because the increase in surface area increased swelling and thereby decreased permeability of the substrate.

Desert globemallow, fourwing saltbush, and rubber rabbitbrush were the most promising species for field testing on bentonite spoil based on this greenhouse trial. These species had the highest survival rates and substantial morphometric and biomass weight increases in response to spoil treatment. They apparently are adaptable to osmotic stress, ion toxicity (halophytic tolerance), and oxygen deficiency. Desert globemallow excreted salt crystals from leaf surfaces as an avoidance mechanism for excessive salt concentration (Levitt 1980). Schuman and Sedbrook (1984) reported fourwing saltbush seeding establishment in the field on bentonite spoils treated with sawdust, but no success with rubber rabbitbrush.

Overall survival rates of big sagebrush, winterfat, yarrow, Rocky Mountain juniper, and fourwing saltbush were markedly low on the controls. However, treatment effects on plant survival, morphometric growth, and biomass indicated that these species increased growth in response to treatment. Big sagebrush has a reported maximum salt tolerance of $17,984 \mathrm{ppm}\left(\mathrm{EC} 28.1 \mathrm{Sm}^{-1}\right)$
(Billings 1949), and winterfat a reported maximum salt tolerance of 173,606 ppm (EC 27.1 S m${ }^{-1}$ ) (Shantz and Piemeisal 1940). Therefore, factors other than salinity appear to have influenced their poor control performance. It may be that the effect of sodium indirectly created an oxygen deficit (by swelling clays) in the root medium. Lunt et al. (1973) reported that big sagebrush has unusually high oxygen requirements for root growth, which accounts for its general absence from fine textured and poorly drained soils.

Russian olive and Rocky Mountain juniper performed most poorly of the tested species. Despite its reported tolerance of alkali and its ability to invade saline flats (Thornburg 1982, Gill 1949, Wright and Bretz 1949), Russian olive seemed to go into salt shock (Levitt 1980) from the onset of the study and never fully recovered its vigor throughout the study. Rocky Mountain juniper, unlike Russian olive, had high survival rates on spoil treated with perlite, sawdust, and vermiculite. Nevertheless, after 6 months, this species appeared to be in continuous stress, as evidenced by its greenishblue, waxy foliation. Its survival in the future was doubtful.

Leaf morphometry, as measured by leaf length, was not a good index to growth for field and greenhouse plantings because of inherent physiological mechanisms that resist size increases, thereby limiting transpiration under drought conditions (Kozlowski 1972). Height, length, width, and twig length measurements are useful indices for measuring plant response, but are dependent upon the plant species. Leaf biomass and stem biomass are the best indicators of growth; however, these measurements involve destructive sampling.

This study documents that growth and survival of drought and salt resistant plants in bentonite spoil generally increased with treatment of spoil. Spoil treatment effects varied with plant species, and no one morphological measurement was best to assess plant growth responses in the greenhouse. However, sawdust, perlite, and vermiculite amendments in general resulted in most consistent increases in morphometric growth, aboveground biomass, and survival rates of the tested species. Sawdust as a bentonite spoil amendment is particularly promising; it is readily available and inexpensive (Voorhees et al. 1984, Schuman and Sedbrook 1984).

These trials demonstrate that under climatic conditions conducive to maximum growth (i.e., the avoidance of extreme temperatures, intense solar radiation, and moisture stress) plants can grow and survive on raw bentonite spoils. Some plants survived on nontreated spoils, and some species showed better growth than on treated spoils; but generally, survival on untreated spoils was not related to morphometric growth. Predictions as to field performance of tested plant species under similar spoil treatments remain speculative.

\section{Literature Cited}

Allen, B.L. 1977. Mineralogy and soil taxonomy. p. 771-796. In: R.C. Dinauer (ed.). Minerals in Soil Environments. Soil Sci. Soc. Amer., Madison, Wis.

Baver, L.D. 1927. Factors affecting the $\mathrm{H}^{+}$-ion concentration of soils. Soil Sci. 23:399-414.

Billings, W.D. 1949. The shadscale vegetation zone of Nevada and eastern California in relation to climate and soil. Amer. Midland Natur. 42:87-109.

Bjugstad, A.J. 1979. Bentonite mine spoil and pit reclamation: A major research problem. p. 1-19. In: Proceedings of the Mineral Waste Stabilization Liaison Committee. Erie Mining Co., Eleveth, Minn.

Carmer, S.G., and M.R. Swanson. 1973. An evaluation of ten pairwise multiple comparison procedures by Monte Carlo methods. J. Amer. Stat. Ass. 68:66-74.

Carolus, R.L., and R.E. Lucas. 1943. Some factors influencing fluctuations in acidity during period of extreme change in the moisture content of soils. Amer. Soc. Hort. Sci. Proc. 42:507-510.

Dollhopf, D.J., and B.J. Bauman. 1981. Bentonite mine land reclamation in the northern Great Plains. Res. Rep. 179, 42 p. Montana Agr. Exp. Sta., Montana State Univ., Bozeman. 
Dellhopf, D.J., E.J. Depuit, and M.G. Klages. 1980. Chemical amendment and irrigation effects on sodium migration and vegetation characteristics in sodic minesoils in Montana. Bull. 736. Reclam. Res. Tech. Montana Agr. Exp. Sta., Montana State Univ., Bozeman.

Epstein, E., J.D. Norlyn, C.W. Rush, R.W. Kingsbury, D.B. Kelley, G.A. Cunningham, A.F. Wrona. 1980. Saline culture of crops: A genetic approach. Science 210:399-404.

Gill, L.S. 1949. Shade trees for the Rockies. p. 72-76. In: Trees, Yearbook of Agriculture 1949. USDA, U.S. Gov. Print. Off., Washington, D.C.

Gries, J.P. 1974. Mineral resources of the Black Hills area, South Dakota and Wyoming. Inf. Circ. 8660 . U.S. Dep. Inter., Bur. of Mines.

Grim, R.E. 1953. Clay mineralogy. McGraw-Hill Book Co., New York.

Grube, W.E., Jr., E.M. Jencks, R.N. Singh, R.M. Smith, and H.A. Wilson. 1971. Mine spoil potentials for water quality and controlled erosion. PB 208817, Nat. Tech. Infor. Serv., U.S. Dep. Comm., 5285 Port Royal Rd., Springfield, Va. 22151. p. 156-171. In: Strip Mining of Coal Environmental Solution, W.S. Doyle (ed.). Noyes Data Corporation, Park Ride, New Jersey 1976, London, England.

Kozlowski, T.T. 1972. Physiology of water stress. p. 229-244. In: C.M. McKell, J.P. Blaisdell, and J.R. Goodin (eds.). Wildland shrubs--their biology and biology and utilization. USDA Forest Serv. Gen. Tech. Rep. INT-1. Ogden, Utah.

Levitt, J. 1980. Responses of plants to environmental stress, Vol. II, Water, Radiation, Salt, and Other Stresses. Academic Press, New York.

Lunt, O.R., J. Letey, and S.B. Clark. 1973. Oxygen requirements for root growth in three species of desert shrubs. Ecology 54:1356-1362.

McKell, C.M. 1978. Establishment of native plants for the rehabilitation of paraho processed oil shale in an arid environment. p. 13-32. In: Robert A. Wright (ed.). The Reclamation of Disturbed Arid Lands. Univ. New Mexico Press, Albuquerque.

Miller, R.G., Jr. 1966. Simultaneous statistical reference. McGraw-Hill Book Co., New York.

Peech, M. 1965. Hydrogen-ion activity, p. 914-926. In: C.A. Black (ed.). Methods of soil analysis. Part 2, Chemical and Microbiological Agron. Series No. 9, p. 771-1572. Amer. Soc. Agron., Madison, Wis.
Schuman, G.E., and T.A. Sedbrook. 1984. Sawmill wood residue for reclaiming bentonite spoils. Forest Products J. 34:65-68.

Shannon, M.C. 1979. In quest of rapid screening techniques for plant salt tolerance. Hort. Sci. 14:587-589.

Shantz, H.L., and R.L. Piemeisel. 1940. Types of vegetation in Escalante Valley, Utah as indicators of soil conditions. U.S. Dep. Agr. Tech. Bull. 1973.

Sieg, C.H., D.W. Uresk, and R.M. Hansen. 1983. Plant-soil relationships on bentonite mine spoils and sagebrush-grassland in northern High Plains. J. Range Manage. 37:289-294.

Snyder, E.F. 1935. Methods for determining the hydrogen-ion concentration of soils. USDA Circ. 56.

Thornburg, A.A. 1982. Plant materials for use on surface-mined lands in arid and semiarid regions. SCS-TP-157, USDA, Soil Conserv. Serv.

Tisdale, S.L., and W.L. Nelson. 1975. Soil fertility and fertilizers. Macmillan Publishing Co., Inc. New York. 3rd edition.

United States Geological Survey (USGS). 1975. Mineral and water resources of South Dakota. In cooperation with: S. Dakota Geol. Surv., S. Dakota Sch. Mines \& Tech., U.S. Bur. Reclam., U.S. Bur. Mines.

U.S. Salinity Laboratory Staff (USSLS). 1954. Diagnosis and improvement of saline and alkali soils. USDA Handb. No. 60. Washington, D.C.

U.S. Testing Company (USTC). n.d. Quality control manual, soil and plant analytical procedures. Richland, Wash.

Wright, E., and T.W. Bretz. 1949. Shade trees for the plains. p. 65-72. In: Trees, Yearbook of Agriculture 1949. U.S. Gov. Print. Off., Washington, D.C.

Voorhees, M.E., D.W. Uresk, and R.M. Hansen. 1984. Atriplex suckleyi (Torrey) Rydb: A native annual plant for revegetating bentonite mine spoils. p. 306-309. In: Tiedeman, A.R.; McArthur, E.D.; Stutz, H.C.; Stevens, R.; Johnson K.L., compilers. Proceedings-symposium on the biology of Atriplex and related chenopods; 1983 May 2-6; Provo, Utah. GTR INT-172. Ogden, Utah: USDA, Forest Ser., Inter. Forest and Range Exp. Sta.; 1984.

Voorhees, M.E. 1984. Amelioration of bentonite spoil to enhance growth of Atriplex suckleyi (Torrey) Rydb. Ph.D. Thesis, Colorado State Univ. Ft. Collins.

\title{
RANGELAND HYDROLOGY
}

\author{
by Farrel A. Branson, Gerald F. Gifford, Kenneth G. Renard, and \\ Aichard F. Hadley
}

Unique in its emphasis on the hydrology of rangelands, primarily arid and semiarid lands, RANGELAND HYDROLOGY provides a text for one aspect of range management where none has existed before. This expanded Second Edition presents in-depth information for those who must manage rangeland or respond to questions about the impacts of land use practices on hydrology.

Included in the new Second Edition are a chapter on modeling with approaches to predicting the effects of land use, and a chapter on the rapidly developing field of snow pack management.

The 352-pages include 197 illustrations, providing rapid access to an assembly of data found nowhere else and useful in the preparation of environmental impact statements. Extensive bibliographic material with each chapter and a subject matter index add to the useableness of the book.

Range scientists and managers, soil conservationists, hydrologists, agricultural engineers, land reclamation specialists, wildlife managers, graduate and undergraduate students and their professors, as well as all interested in the hydrology of arid lands will find RANGELAND HYDROLOGY a valuable addition to their libraries. (352 pages paper laminated cover $\$ 15.00$ US) 